To Cite This Article: Gülçin, D. \& Yılmaz, K. T. (2020). Quantification of the change in ecological connectivity using a GIS-based model and current complexity metrics. International Journal of Geography and Geography Education (IGGE), 42, 689-701.

\title{
QUANTIFICATION OF THE CHANGE IN ECOLOGICAL CONNECTIVITY USING A GIS-BASED MODEL AND CURRENT COMPLEXITY METRICS
}

\begin{abstract}
Landscape patterns have been undergoing various changes on account of environmental and human factors. These changes affect ecological connectivity of landscapes; therefore existing connections are necessary to maintain sustainable habitats. Connectivity is associated with the diversity and composition of landscape structure. For this reason, when studying ecological connectivity, it is relevant to analyze the changes in diversity, composition, and fragmentation of landscape patterns. This study was conducted in Manisa, Turkey, where the impact of industrialization and urbanization on landscape is very significant. The aim of this study is to assess the changes in ecological connectivity based on an ecological connectivity model and landscape metrics that characterize landscape heterogeneity between 2000 and 2018. Largest Patch Index (LPI), Marginal Entropy (ENT), and Relative Mutual Information (RELMUTINF) were utilized to evaluate the fragmentation, diversity, and composition of the landscape, respectively. As a result of this study, forest loss was found to be 12,970 ha based on 18 years of land change. This has an adverse impact on the ecological connectivity, resulting in a decrease in the high and very high connectivity areas from $71.5 \%$ to $53.5 \%$. At the landscape level, the decrease in the LPI from 3.55 to 2.30 shows that fragmentation has increased in Manisa. Since larger patches have higher species diversity in general, a drop in the LPI value indicates that species diversity has decreased over time. The most substantial observed changes include the homogenization of agricultural land and the fragmentation of forests. The results demonstrate that a combination of ecological connectivity and landscape metrics would be highly effective for extensive planning and interpretation.
\end{abstract}

Keywords: Landscape Connectivity, Landscape Pattern, Landscape Composition, Fragmentation, Landscape Mosaic

\footnotetext{
${ }^{1}$ Correspondence to: Postdoctoral Fellow, Urban Forestry Research in Action, Department of Forest Resources Management, The University of British Columbia, 2329 West Mall, V6T 1 Z4 Vancouver, BC Canada., https://orcid.org/0000-0001-7118-0174., derya.gulcin@ubc.ca

2 Faculty of Agriculture, Department of Landscape Architecture, Aydın Adnan Menderes University, Aydın, TURKEY.

3 Prof., Faculty of Architecture, Department of Landscape Architecture, Cukurova University, Adana, TURKEY., https://orcid.org/0000-0003-26631583., tuluhan@cu.edu.tr
} 


\section{INTRODUCTION}

Connectivity is defined as the movement ability and ecological behavior/requirement of species that are under consideration (Taylor et al., 1993; Olds et al., 2012). Connectivity enables interaction between species and landscapes in landscape composition, and therefore it is significant for the sustainability of ecological processes (Forman, 1995). Recently, habitat networks have been formed on the basis of conservation-based practices of the connectivity paradigm (Velázqueza et al., 2019). While landscape connectivity is a key factor for ecology, it is also useful for the genetic structure of populations under threat due to habitat fragmentation and climate change (Guan et al., 2019). Additionally, connectivity is a function of habitat area, habitat quality, and species distribution capacity (Hodgson et al., 2009; Velázqueza et al., 2019). In landscape ecology, connectivity enables us to understand the current structure of a landscape (Tischendorf and Fahrig, 2000).

There is a strong link between landscape patterns and ecological processes (Jorgensen and Faith, 2014). Landscape ecology theory offers various methods for characterizing landscape structures and measuring change over time for landscape planning (Turner, 1989; Christensen et al., 2017). These include metrics that allow for landscape structures to be mathematically expressed, which aids in the development of alternative plans in landscape management (McGarigal, 2002; Uuemaa et al., 2009; Nowosad and Stepinski, 2019). Connectivity is generally considered to be a highly relevant landscape qualification, as it contributes to conservation biology in terms of population dynamics and species diversity on both a local and regional scale (Velázqueza et al., 2019). Determining habitat corridors is a classic approach to enabling the management of landscape connectivity (Lindenmayer et al., 2008). This makes a contribution to the determination of a conservation strategy to prevent adverse effects of urbanization, infrastructure development, and other urban activities on natural connections (Pino and Marull, 2012; Dupras et al., 2016).

The maintenance of an ecological network requires the protection of existing green spaces, creation of new spatial forms, and connection among patches. The main elements of landscape connectivity are green paths, corridors formed by green paths, and green belts (Linehan et al., 1995; Taylor et al., 1995; Fábos et al., 2006). The level of ecological connectivity can enable or prevent the movement of patches in landscapes (Tischendorf and Fahrig, 2000; Wu et al., 2017). Ecological connectivity significantly affects ecological processes, such as migration and species distribution (Beier and Noss, 1998). Additionally, ecological connectivity enhances landscape integrity (Collinge, 1998) and ensures a sustainable balance in natural ecosystems (Raison et al., 2001; Crist et al., 2005).

Connectivity is generally divided into two distinct forms: structural and functional (Goodwin, 2003). Structural connectivity entails the analysis of landscape patterns regardless of species or ecological processes while functional connectivity entails the evaluation of contact and closeness between habitat units (Saura et al., 2011). LaPoint et al. (2015) analyzed 174 ecological connectivity studies on an urban scale and found that formulated hypotheses and a priori estimates are underutilized in the designs and methods of many papers. They noted that functional connectivity is a significant factor in many studies about ecological connectivity and ecological-network mapping. They also indicated that methods for analyzing the connectivity of species diversity in fragmented landscapes have continually developed. Ecological connectivity studies about species diversity and genetic data not only constitute a base for testing the effects of ecological connection networks, but also help to sustain the different connections and habitat areas that enable the survival of species and their potential distributions (Luque et al., 2012; DiLeo et al., 2017). Landscape diversity, as well as genetic structure and species diversity, is important for assessing connectivity (Yazgi and Yilmaz, 2017; Qian et al., 2018). For landscape diversity to be assessed within the scope of ecological connectivity, landscape-change processes must be understood (Jongman et al., 2019).

In nearly all historical cases of urban development, the process has negatively affected the landscape. An inevitable long-term result of urban development is the loss of biodiversity brought about by the fragmentation and isolation of natural and semi-natural habitats. During the 2014 Convention on Biological Diversity in Montreal, habitat loss and fragmentation were deemed one of the most significant threats to global biodiversity. The meeting of the Intergovernmental Science-Policy Platform on Biodiversity and Ecosystem Services in Paris emphasized that natural areas are decreasing rapidly, and extinction rates are rising; these changes constitute a global ecological milestone (García-Díaz et al., 2019). High levels of fragmentation make landscape rehabilitation much harder both ecologically and economically.

To reduce the impact of habitat fragmentation, connectivity must be approached holistically. The provision of ecological connectivity relies on the planning of green networks (Zhang et al., 2019). Article 10 of the EU Habitats Directive (Council Directive 92/43/EEC) bases the management of linear or continuous landscape features that are necessary for the movement of wild species on landscape connectivity. The management of landscape features within the scope of "connectivity" is significant for sustainable development (Vogiatzakis et al., 2006). 
Theories and methodological approaches that evaluate ecological connectivity have become important subjects in landscape ecology (Marulli and Mallarach, 2005; Mallarach and Marulli, 2006; Chang et al., 2012; Hepcan, 2013; Wu, 2017). Ecological connectivity plays a key role between ecological structures, functions, or landscape classes is ecological connectivity (Tischendorf and Fahrig, 2000; Carlier and Moran, 2019). Connectivity assessment is performed in accordance with quantitative methods, such as connectivity models and landscape metrics (Pino and Marull, 2012). McRae et al. (2012) highlighted that the primary methods used to determine ecological connectivity are least-coast corridor modeling, circuit theory, individual-based movement model, and centrality analysis. Broadly speaking, methods that are cost-effective and easily integrated with ecological connectivity are used in landscape ecology studies. For example, Marulli and Mallarach (2005) indicated that built-up areas are regarded as barriers that constitute $18 \%$ of large cities and have a negative effect on $57 \%$ of their ecological connectivity. In their study conducted in Montreal between 1966 and 2010, Dupras et al. (2016) assessed land-use changes and determined that ecological connectivity decreased over time. Wu et al. (2017) used satellite images of Dongshan Island to evaluate the changes in ecological connectivity across three years, using a least-cost model with the Barrier Effect Index (BEI) and the Ecological Connectivity Index $(\mathrm{ECl})$. Their results indicate that new roads and agricultural lands are leading to a decline in landscape connectivity.

While the extent of habitat loss and the factors that impact diversity in landscapes have been studied, structural connectivity still needs to be improved for particularly broad landscapes (Zwoliński et al., 2018). A few studies comprehensively detail the potential networks in regional landscapes (De Montis et al., 2016). Maintaining landscape sustainability is associated with existing ecological connectivity; ecological networks emphasize the function of the landscape and are investigated by landscape planners to prevent or ease movements and flows in land mosaic (Dramstad et al., 1996). Planners generally take landscape patches between habitats into account, rather than spatial, ecological, or other landscape factors, while modeling integrated, structural, and functional landscape connections. For the sustainability of connectivity, landscape features such as distance, size, and density should be measured; in other words, landscape patterns should be analyzed, barriers among habitats should be determined, and potential corridors should be designated (Nor et al., 2017).

Conserving biodiversity - strengthening or preserving existing levels of ecological connectivity - is an especially important strategy against the destructive effects of habitat fragmentation stemming from improper land use or climate change (Saura et al., 2011). The primary research question is: How can be temporal changes of ecological connectivity assessed with recent complexity metrics? This study aims to make a quantitative assessment of ecological connectivity change in Manisa, Turkey, where has important ecological areas with a high level of landscape diversity. Within the scope of this study, a GIS-based ecological connectivity model and various landscape metrics were used, based on landscape mosaic data. The changes in the ecological connectivity between 2000 and 2018 were analyzed by the ecological connectivity model and interpreted with the landscape metrics. The novelty of this study is to assess the changes in ecological connectivity with various landscape metrics incorporating recent entropies such as marginal entropy (ENT) and relative mutual information (RELMUTINF).

\section{MATERIAL AND METHOD}

\section{Study Area and Data}

Manisa is the 14th largest province in Turkey. With a rapidly growing population, seven of its 17 districts (Yunusemre, Akhisar, Şehzadeler, Turgutlu, Salihli, Soma, Alaşehir) have a population over 100,000. According to TUIK data (TUIK, 2019), the population of Manisa rose from 1,260,169 in 2000 to 1,429,643 in 2018. The province is on the west side of the Anatolian Peninsula in the middle of the Aegean Region (Figure 1). 


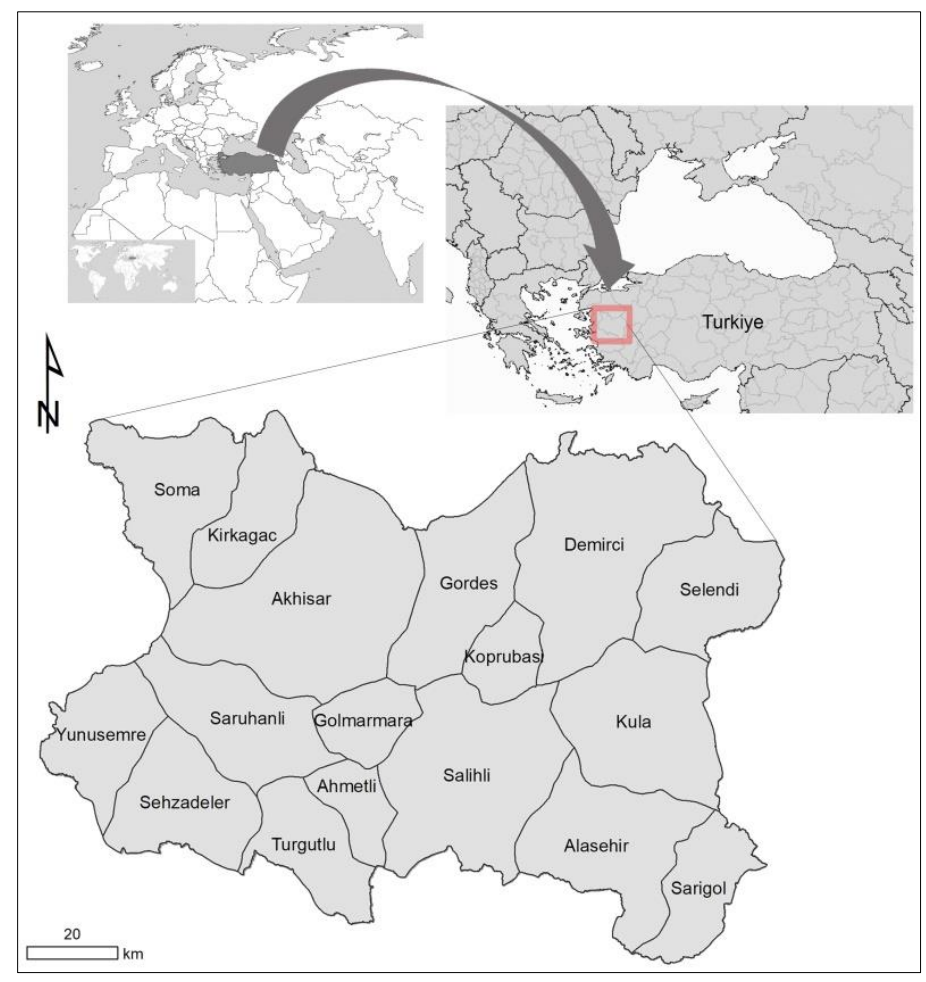

Figure 1: Geographical Location of the Study Area

Eighty-two percent of the provincial acreage is located within the boundaries of the Gediz Basin. The main collector of the basin, the Gediz River, originates in the upper basin; several tributaries feed into the river, and it flows into the Gulf of Izmir (Aegean Sea). There are several coastal wetlands in the delta such as the river, lakes, estuary, shallows, lagoons, saltpans, mudflats, reed beds, salt marshes, farmland, and hills. The Gediz River, at over $400 \mathrm{~km}$, runs through several rural settlements and big cities, meandering west to the Aegean Sea. Therefore, the Gediz Delta is formed by the confluence of the Gediz River and the Aegean Sea; the delta is home to brackish, salt, and fresh water. River flow and water-type flux affect the biodiversity and content of the delta wetlands (Kaplan and Hepcan, 2009). There are several issues involving water, such as drought and competition (Gorguner et al., 2019).

The Gediz Delta is internationally renowned for its high diversity of bird species. With both fresh water and salt water, the delta is a suitable area for the nutrition, accommodation, and reproduction of many species with varying habitat needs -it hosts approximately 220 waterbird species (Kocataş et al., 1988), including the Dalmatian pelican, flamingo, lesser kestrel, pied avocet, stone curlew, glareolidae, snowy plover, spur-winged lapwing, Mediterranean gull, little tern, and Caspian tern, which all benefit from the fact that the delta meets the Important Bird Area criteria. Many species spend the winter in the delta, including the pygmy cormorant, flamingo, ruddy shelduck, and Dalmatian pelican.

Manisa has several notable cultural and natural landscape features, such as Spil Mountain National Park, Mesir Natural Park, Süreyya Natural Park, and the Kula Fairy Chimneys Nature Monument. Seventy-six endemic plant species were discovered in Spil Mountain National Park (Altan et al., 2017). According to the first botanical studies in Kula Fairy Chimneys, eighteen endemic species were determined to be utmost-importance species; of these, 13 were deemed to be under threat according to the IUCN (İşık-Gürsoy et al., 2016).

There are various ecosystems in Manisa, some of which are sensitive, critical wildlife ranges. Environmental pollution in Manisa has increased over the last few years as a result of industrial and agricultural activities-its landscape is now under severe pressure (Gülersoy, 2013). Golmarmara Lake, one of the province's natural areas, has deteriorated because of agriculture intensification, water-regime intervention, and waste (Arı and Derinöz, 2011). These detrimental landscape changes were critical in the choice of Manisa as a study area.

The materials of this study were CORINE Land Cover maps from 2000 and 2018, which were obtained for free from the Copernicus Land Monitoring Service website (EEA, 2019), and an Open Street Map (OSM) from 2018 downloaded for main-road mapping from https://www.openstreetmap.org/. The main roads from 2000 were digitized in Google Earth Pro as kmz files and converted into vector data in ArcMap 10.7. 


\section{Method}

The methods of this study consist of four parts: (1) landscape classification, (2) calculation of landscape metrics (3) production of ECI maps, (4) assessment of ecological-connectivity changes. 2000 and 2018 CORINE Land Cover (CLC) datasets were used for landscape classification. Landscape classification and landscape-metric calculation, and the ecological-connectivity model are described under separate titles.

\section{Landscape classification and landscape-metric calculation}

CLC datasets have been used for various environmental analyses and models, though their spatial resolution is limited (Vizzari et al., 2018). The CLC dataset, represented in 44 classes and three levels, was rearranged in line with the study aims. Landscape classification resulted in landscape classes as follows: artificial surface, unproductive, cropland, forest, other vegetation association, and water (See Table 1).

\begin{tabular}{|cc|}
\hline \multicolumn{2}{|c|}{ Table 1: Reclassification of CLC Classes } \\
\hline CLC Macro-class code & CLC code (level 3) \\
\hline $111,112,121,124,131,133,142$ & Artificial surface \\
$331,332,333,334$ & Unproductive \\
$211,212,221,223,231,242,243$ & Cropland \\
$311,312,313$ & Forest \\
$321,323,324$ & Other vegetation association \\
$411,422,512$ & Water \\
\hline
\end{tabular}

Landscape metrics quantify composition, fragmentation, and diversity and provide information to make a comprehensive assessment of ecological connectivity and to describe landscape changes. In this study, Largest Patch Index (LPI) was used to assess fragmentation, Marginal Entropy (ENT) was utilized to estimate landscape diversity, and Relative Mutual Information (RELMUTINF) was employed to assess landscape composition. An open-source R package, Landscapemetrics, was used to calculate landscape metrics (Hesselbarth et al., 2019). This package borrows the calculation of LPI from FRAGSTATS v4 (McGarigal et al., 2012) while the other metrics have been recently introduced by Nowosad and Stepinski (2019).

LPI is one of the important metrics for assessing landscape fragmentation. It quantifies landscape composition through the percentage of total landscape area encompassed by the largest patch. According to Lavers and Haines-Young (1993), larger patches include more species. LPI is calculated as follows, where $a_{i j}$ is area $\left(\mathrm{m}^{2}\right)$ of patch ij and A is total landscape area $\left(\mathrm{m}^{2}\right)$ :

$$
\mathrm{LPI}=\frac{\max \left(\mathrm{a}_{\mathrm{ij}}\right)}{\mathrm{A}}(100)(\mathrm{I})
$$

The single variable $y-a$ class of the neighboring cell in a pair of cells was considered when calculating ENT. $p(x, y), p\left(y_{j}\right)=\sum_{i} p\left(x_{i}, y_{j}\right)$ was marginalized to obtain the distribution of $p(y)$. Shannan entropy was used to calculate the informational content of ENT:

$$
\mathrm{H}(x)=-\sum_{\mathrm{j}=1}^{\mathrm{k}} \mathrm{p}\left(y=c_{j}\right) \log _{2} \mathrm{p}\left(y=c_{j}\right)(\mathrm{II})
$$

$H(x)$ is the number of bits necessary on average to determine a cell class. Often referred to as pattern diversity, it measures the compositional complexity of a pattern (check the formula below for $H(x)$ ordering of the evaluation set of landscapes).

The mutual information value tends to grow with various landscapes because of spatial autocorrelation. To correct this tendency, the relative mutual information can be computed by dividing the mutual information by the ENT. To compare spatial data with a different number and category distribution, RELMUTINF is used, which has a range between 0 and 1 and is calculated as:

$$
\mathrm{U}=\mathrm{I}(y, x) / \mathrm{H}(y)(\mathrm{III})
$$

\section{Ecological connectivity model}

The method of analyzing ecological connectivity is based on the least-coast model. Before applying the model, barriers and ecological functional areas are defined. Resistance surfaces represent barriers such as roads, main communications, and built-up areas. Ecological functional areas consist mostly of natural landscapes, including 
protected areas, core habitats, and forests. Modeling ecological connectivity entailed the use of the Ecological Connectivity Index (ECl), which is a quantitative landscape-ecology method introduced by Marulli and Mallarach (2005). The barriers show all artificial land utilizations that prevent energy, information, or matter flowing along the matrix (i.e., landscape resistance; Forman, 1995; Marulli and Mallarach, 2006; Dupras et al., 2016). The Barrier Effect Index (BEI) is presented below (Marulli and Mallarach, 2005):

$$
\mathrm{BEI}=Y_{i} / Y_{\max }(\mathrm{IV})
$$

$Y_{i}$ is the value of the barrier effect in a pixel. $Y_{\max }$ is the maximum value of the barrier effect. In the formula, $Y_{i}$ and $Y_{\text {max }}$ are described as the value of the barrier effect in a pixel and the maximum value of a pixel, respectively. These values are obtained using the barrier effect value, Ys, which is calculated as follows (Marulli and Mallarach, 2005):

$$
\mathrm{Ys}=\sum_{\mathrm{s}=1}^{\mathrm{s}=\mathrm{n}}\left(\begin{array}{l}
\mathrm{n} \\
\mathrm{k}
\end{array}\right) \mathrm{Ys}=\sum_{\mathrm{s}=1}^{\mathrm{s}=\mathrm{n}}\left[b_{s}-k s_{1} \ln \left(k s_{2} \mathrm{~d}_{\mathrm{s}}{ }^{\prime}+1\right)\right](\mathrm{V})
$$

Ys is the barrier impact value of artificial land types; $\mathrm{n}$ is the number of the artificial land types $(\mathrm{n}=1-3) ; b_{s}$ is the barrier weight of three types (See Table 2); $\mathrm{d}_{\mathrm{s}}^{\prime}$ is the obtained distance. $\mathrm{d}_{\mathrm{s}}^{\prime}$ was obtained through cost-distance analysis using ArcMap 10.7, based on the surface database with all potential and origin surface data for every barrier type. $k s_{1}$ and $k s_{2}$ are the fixed values created for logarithmic decrement. Cost-distance analysis uses two databases. One of them is the origin surface for any barrier type and the other one is the impedance surface. For the initial stage of the model, the areas that define barriers are determined as artificial surfaces, main roads, and water. The barrier weights used to create the BEI maps $\left(b_{s}\right)$ and the coefficients are shown in Table 2.

\begin{tabular}{|ccccc|}
\hline \multicolumn{5}{c|}{ Table 2: Basic Barrier Types $\left(b_{s}\right)$ in Manisa } \\
\hline Code & Type & Weight $b_{s}$ & $k_{1}$ & $k_{2}$ \\
\hline B1 & Artificial surfaces & 40 & 44.420 & 0.063 \\
B2 & Main Roads & 80 & 22.210 & 0.126 \\
B3 & Water & 60 & - & - \\
\hline
\end{tabular}

The coefficients, influence distance (an), and influence value (An) used for BEI, are empirical; they are part of the method introduced by Marulli and Mallarach (2005). After BEI was calculated, the connectivity index formula was calculated using ArcMap 10.7. The impact matrix is presented in Table 3.

\begin{tabular}{|ccc|}
\hline Table 3: Impact Matrix for the Calculation of the Barrier Effect Index in Manisa ( $a_{\mathrm{n}}$ : Influence Distance, $\mathrm{A}_{\mathrm{n}}$ : Influence Value) \\
\hline Type & $\mathrm{a}_{\mathrm{n}}$ & $\mathrm{A}_{\mathrm{n}}$ \\
\hline Unproductive & $1000 \mathrm{~m}$ & 0.10 \\
Forest & $750 \mathrm{~m}$ & 0.13 \\
Other vegetation & $750 \mathrm{~m}$ & 0.13 \\
Cropland & $500 \mathrm{~m}$ & 0.20 \\
Artificial surface & $250 \mathrm{~m}$ & 0.40 \\
Water & $250 \mathrm{~m}$ & 0.40 \\
\hline
\end{tabular}

The value of BEI below zero is insignificant. Therefore, when computing the BEI, negative values should be prevented. $\mathrm{BEI}$ is a relative index; it was designed to give values between 1 and 10 for areas where it is applied. One of the reasons for this adjustment is the high variation in continuous values; the other is the difficulty to measure absolute terms of the barrier effect in different ecosystems (Dupras et al., 2016). When mapping ECl, cost distance analysis was applied using ArcMap 10.7. Natural areas are important components of the ecological connectivity network, and therefore they are considered as "ecological functional areas". As an origin surface the map of ecological functional areas was used, and as an impedance surface, the total Ys map was used in the analysis. ECl was calculated using the formula below (Marulli and Mallarach, 2005):

$$
\mathrm{ECI}=10-9\left[\ln \left(1+x_{i}-x_{\min }\right) / \ln \left(1+x_{\max }-x_{\min }\right)^{3}\right](\mathrm{VI})
$$

where $x_{i}$ is the distance value in a pixel, and $x_{\min }$ and $x_{\max }$ are the minimum and maximum ecological distance values, respectively. $x_{\max }$ is the maximum possible adapted cost distance. When $x_{\min }=0$ and $x_{\max }=x_{t}$, the index is called the basic ecological connectivity index $\left(\mathrm{ECl}_{\mathrm{b}}\right)$ and is determined by adding the $\mathrm{ECl}$ value calculated for an ecological functional area and dividing it by the total ecological functional area. $\mathrm{ECl}_{\mathrm{b}}$ is calculated as follows (Marulli and Mallarach, 2005): 


$$
\mathrm{ECI}_{\mathrm{b}}=10-9\left[\ln \left(1+x_{i}\right) / \ln \left(1+x_{t}\right)^{3}\right](\mathrm{VII})
$$

\section{RESULTS AND DISCUSSION}

The CLC dataset, represented in 44 classes and 3 levels, was reclassified in line with the study aims to conduct landscape classification. Landscape classes were artificial surface, unproductive, cropland, forest, other vegetation association, and water (See Figure 2). Landscape classification maps constructed for 2000 and 2018 are shown in Figure 2. When the land-cover change was examined, it became clear that the most significant change was in artificial surface.
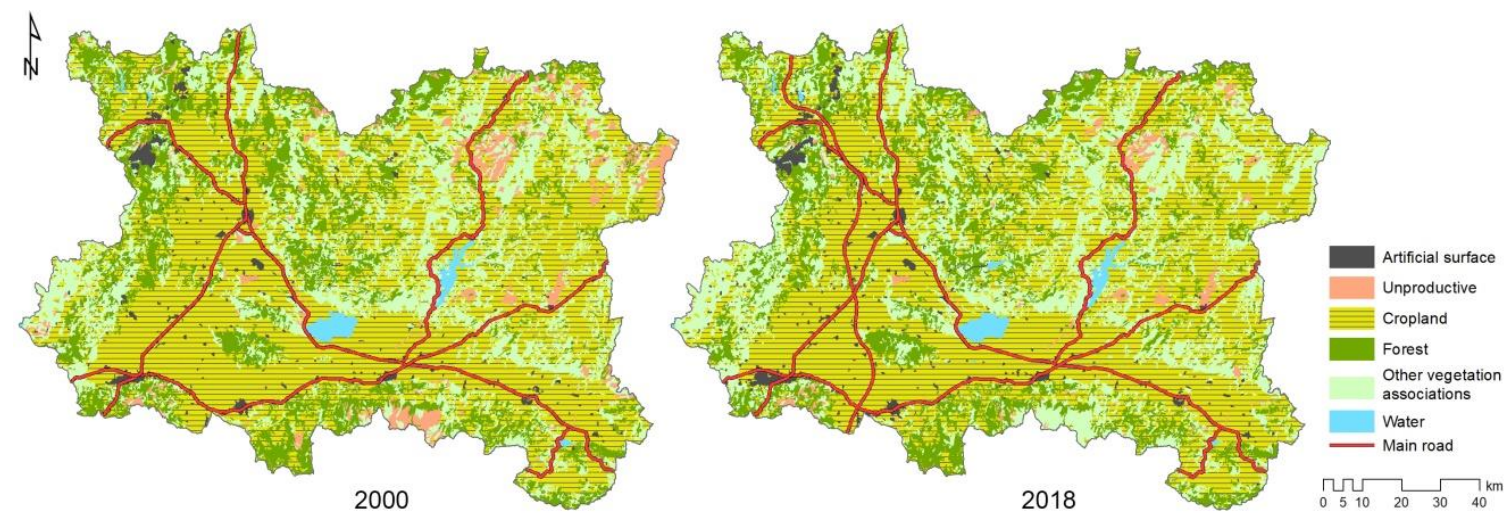

Figure 2: Manisa Land-Cover Change (2000-2018)

While there was a slight change in cropland, unproductive areas decreased to a more significant extent. Forest area was decreased by approximately 12,970 hectares (See Table 4). Gülersoy (2013) referenced the increase in planting practices by the Izmir Regional Directorate of Forestry in the study area and noted that species with a high economical yield, such as Pinus pinea L., were planted in high numbers. Despite these planting practices, there has been a decrease in tree cover. Water surface increased because of dams built on the Gediz River and its tributaries, which developed irrigation. While croplands increased in size thanks to agricultural policy, croplands around urban settlements were integrated into cities and, thus, grew more fragmented. The rapid development of organized industrial estates in Manisa is due to the short distance between Manisa and Izmir (Gülersoy, 2013). The development of industry in Manisa resulted in an increase of croplands in order to provide raw material to the industry. Another reason for this increase is enhanced irrigation due to the increasing demand for fresh vegetables and fruits stemming from a growing population.

\begin{tabular}{|c|c|c|c|c|c|}
\hline \multicolumn{6}{|c|}{ Table 4: Land Cover Change in Manisa (2000-2018) } \\
\hline \multicolumn{3}{|c|}{2000} & \multicolumn{2}{|c|}{2018} & \multirow[b]{2}{*}{ Change (\%) } \\
\hline Land Class & ha & $\%$ & ha & $\%$ & \\
\hline Artificial surface & $25,220.11$ & 1.89 & $32,196.12$ & 2.42 & +0.53 \\
\hline Unproductive & $49,596.17$ & 3.72 & $20,837.60$ & 1.56 & -2.16 \\
\hline Cropland & $700,157.47$ & 52.57 & $706,260.29$ & 53.02 & +0.45 \\
\hline Forest & $232,955.28$ & 17.49 & $219,986.20$ & 16.52 & -0.97 \\
\hline Other vegetation & $311,150.40$ & 23.36 & $338,866.58$ & 25.44 & +2.08 \\
\hline Water & $12,872.94$ & 0.97 & $13,805.60$ & 1.04 & +0.07 \\
\hline Total & $1,331,952.39$ & 100 & $1,331,952.39$ & 100 & \\
\hline
\end{tabular}

At the landscape level, the decrease in the LPI from 3.55 to 2.30 shows that fragmentation has increased in Manisa. As larger patches are known to contain more species, it can be assumed that diversity also decreased. ENT points out little change in the overall land cover. An analysis of ENT values points out that the 2018 values are smaller than the 2000 values. This suggests that overall diversity has also decreased (See Figure 3). 


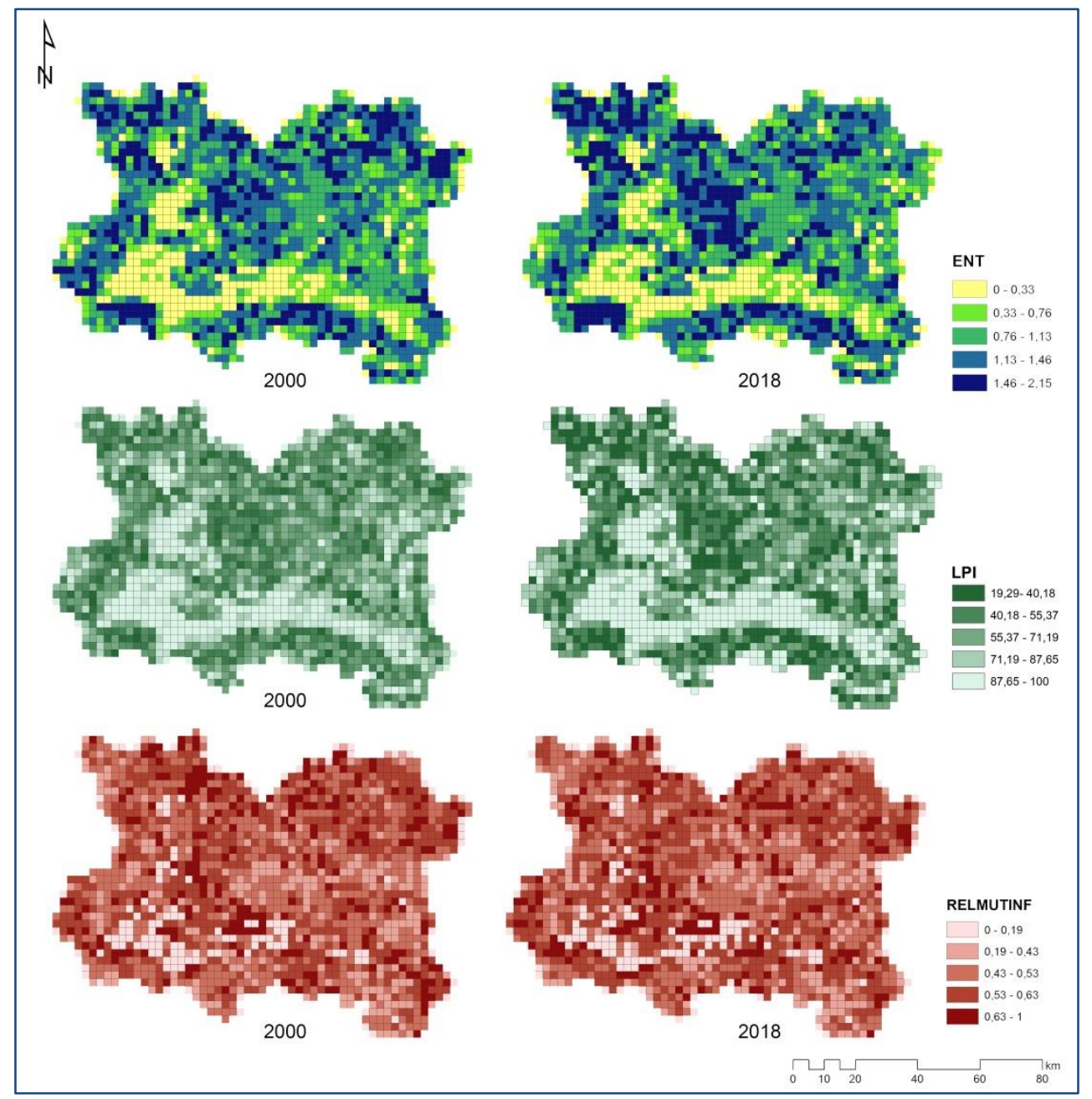

Figure 3: ENT, LPI, and RELMUTINF Maps (Spatial Distribution Expressed by $3 \times 3$ km Cells)

Ecological functional areas consist of broad-leaved forest, coniferous forest, mixed forest, sclerophyllous vegetation, and transitional woodland shrub, all of which have high biodiversity values. The analysis in this study clearly shows that land-use changes in Manisa caused structural changes. Consequently, the ECl value in the connectivity map was rescaled as the value range suggested in the connectivity model, 1-10. The values were assigned as follows: 1-2, "no connectivity"; 2-4, "low connectivity"; 4-6, "medium connectivity"; 6-8, "high connectivity"; and 8-10, "very high connectivity" (See Figure 4). ECI maps illustrate that areas losing connectivity are marginally increasing; those with high or very high connectivity are decreasing and fragmented.

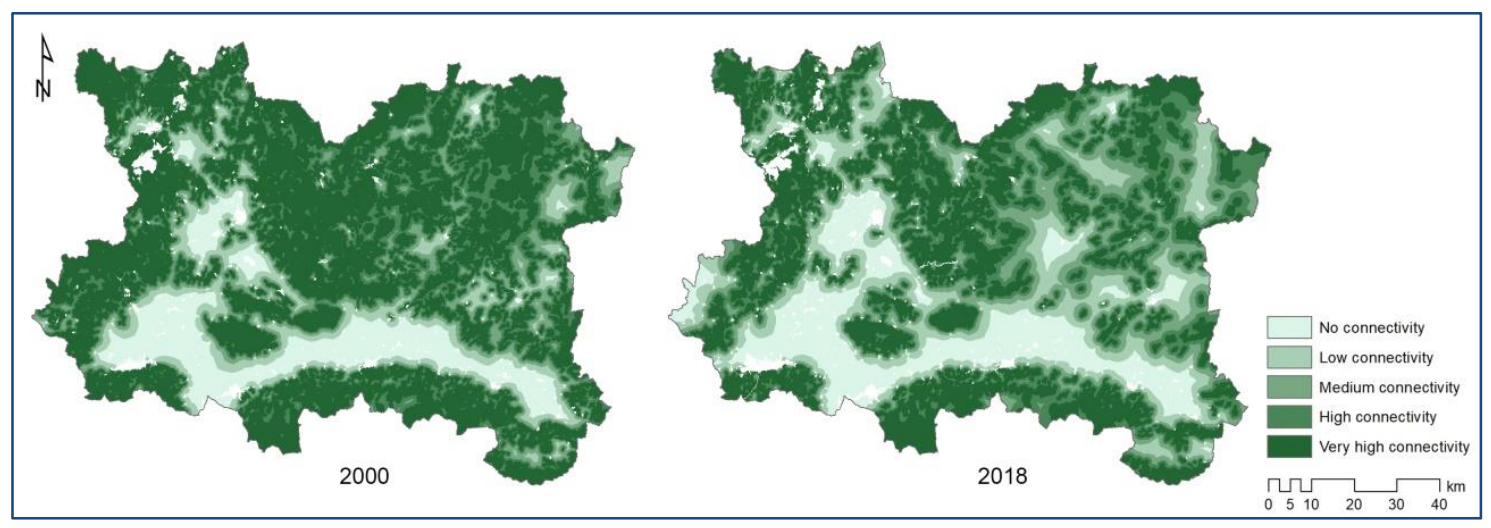

Figure 4: ECI Maps, 2000 and 2018 
No-connectivity and low-connectivity areas (which include urban settlements) increased from $15.83 \%$ to $24.14 \%$ of the total area; medium-connectivity areas increased from $12.6 \%$ to $22.4 \%$; high- and very high-connectivity areas decreased from $71.57 \%$ to $53.46 \%$ (See Figure 5). The changes in area and connectivity are presented in Figure 5. The increase in the no- and low-connectivity areas stems from urban development, which is the result of a growing population. Over the observed 18-year period, the population of Manisa rose from 1,260,169 to 1,429,643 (TUIK, 2019). The industrial development in Manisa, the secondary trade center in the Aegean Region, played an important role in this change; population density and unplanned urbanization significantly impacted the city (MV, 2020).

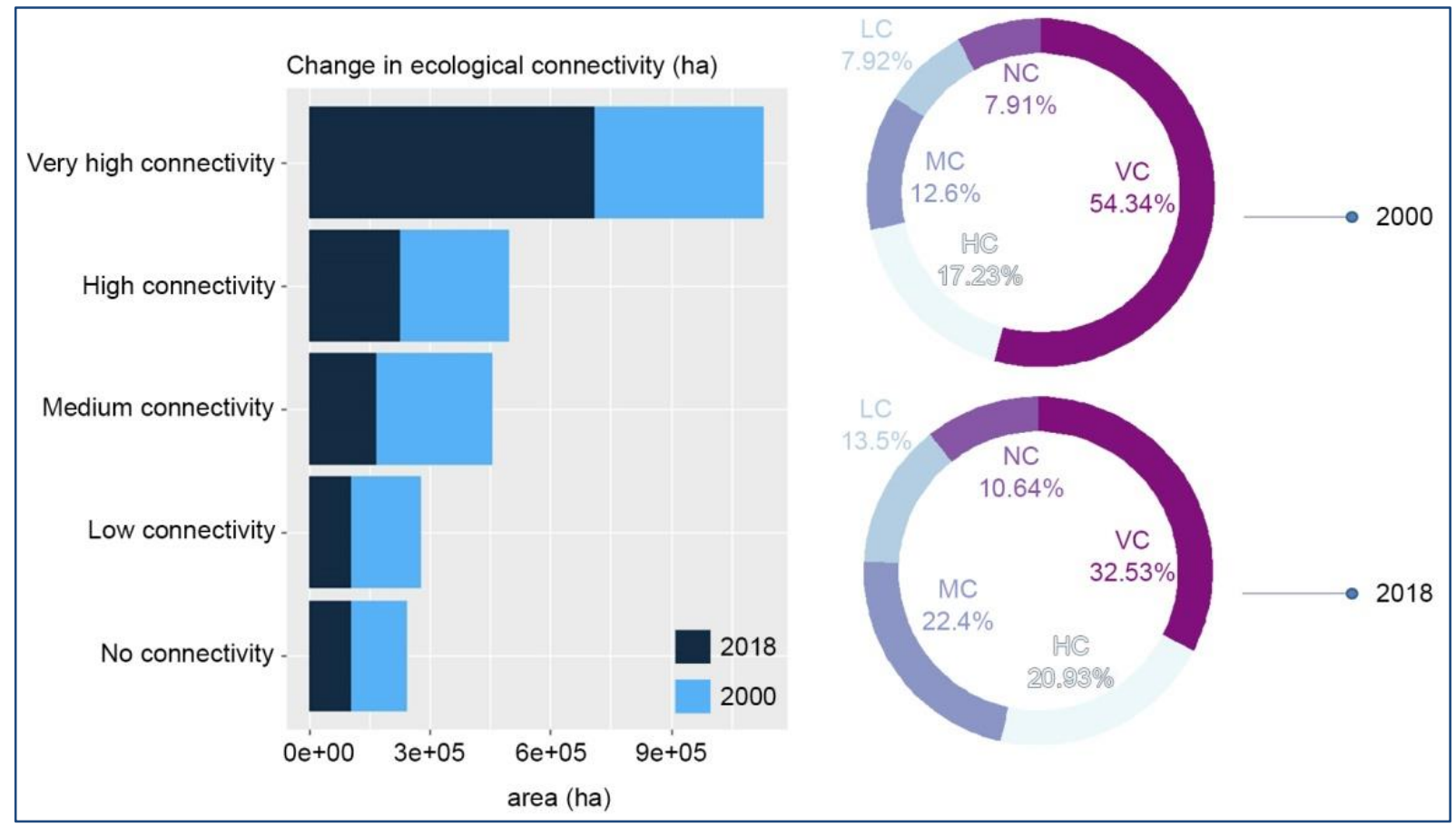

Figure 5: Bar Chart Showing Ecological Connectivity Changes; Donut Charts Representing ECl Classifications in Manisa (VH: Very High Connectivity; HC: High Connectivity; MC: Medium Connectivity; LC: Low Connectivity; NC: No Connectivity)

There are lessons that can be learned from the findings of this study. First of all, protecting natural areas and isolating them from the rest of the landscape by the construction of barriers decrease ecological connectivity, resulting in landscape fragmentation. This can be understood from the final connectivity maps (See Figure 4). Despite the protection status of forests and Spil Mountain National Park, they became isolated due to the land encroachment such as construction of new roads, scattered pattern of urban and rural settlements. For this reason, a holistic approach needs to be adopted in terms of protecting ecological networks in spatial planning of Manisa. In addition to the findings of the ecological connectivity model, recent complexity metrics showed the temporal changes in the spatial heterogeneity. The LPI maps suggest that an increase in croplands caused the fragmentation particularly around the Gediz plain. The ENT map illustrates there was a decrease in both diversity and complexity, while the RELMUTINF map shows landscape composition was slightly changed, and fragmentation was increased. Despite the overall increase in croplands, there was a decrease around urban settlements; over the observed 18-year period, these areas became part of the no-connectivity class. Through the evaluation of landscape metrics, the amount of forest patches increased, but both diversity and complexity decreased in Spil Mountain National Park.

Secondly, it can be understood from the final complexity maps that these metrics are capable of showing ecological dissimilarity, and therefore it is very useful to combine them with ecological connectivity model in order to provide a better understanding of temporal change of ecological processes (Tscharntke et al., 2012; Dupras et al., 2016). Since ecological functional areas have a decrease in ecological connectivity, monitoring temporal changes is relevant (Watson et al., 2017). For this reason, protecting policy needs to be revised in Manisa. This will be helpful especially for the ecological network in terms of nature conservation and spatial planning.

Connectivity maps do not always show functional units that need to be protected; rather, they often map units that may not be currently viable. However, they provide good opportunities for enhancing connectivity (McRae et al., 2012). In this context, ecological connectivity maps generally represent visons that can be valuable for future landscapes. Therefore, identifying ecological functional areas and barriers and assessing them with a least cost model contribute to 
site specific conservation plans. The quantitative methods that applied in this study can be supported with alternative planning scenarios. To do so, rigorous conservation plans can be produced.

The ECl can be adjusted to local conditions if empirical data is available (Wu et al., 2017). To conduct this study, we did not have any experimental data, and therefore we used empirical values from published papers to apply the least cost model (Marulli and Mallarach, 2005; Dupras et al., 2016; Indrayani et al., 2017). This can be considered as the limitation of this study. However, Wu et al. (2017) stated that the empirical values provided by Marulli and Mallarach (2005) reasonably reflect dynamic changes in the $\mathrm{ECl}$.

\section{CONCLUSION}

Broadly speaking, landscape fragmentation is a common result of human activities. The effects of the fragmentation depend on the changes in the connections between habitats in a landscape. Therefore, analyzing connectivity change is a top priority for landscape conservation. There is a strong relationship between ecosystem characteristics, landscape composition, and landscape configuration. ENT and RELMUTINF have been recently integrated into landscape ecology in order to understand this relationship, which quantifies both landscape complexity and landscape diversity. Overall, this study not only assessed ecological-connectivity changes in Manisa between 2000 and 2018, but also changes in the composition and diversity of the landscape. Results show that there has been a connectivity loss over time. The most substantial observed changes include the homogenization of agricultural land and the fragmentation of forests.

It can be deduced from the land-use change values that connectivity loss occurs mostly due to the increase in artificial surfaces and new roads. This influences habitats, and therefore may pose a serious threat to biodiversity. Furthermore, fragmentation can have tremendous negative effects on ecological quality of these habitats. Previous literature has shown how connectivity loss has an adverse impact on biodiversity (Correa Ayram et al., 2016).

Due to the rapid increase in agricultural practices, natural areas have become less prominent in Manisa (Altan et al., 2017). As a part of the "Large Plain Project," which seeks to prevent the misuse of agricultural areas, the Manisa, Akhisar, and Kirkagac plains were placed under protection in 2017, when plains with high agricultural potential were declared as agricultural-protection areas. The effects of this decision on conservation will be evident in the years to come. If the croplands are not expanded in the province, it may affect the connectivity, and high-level connectivity can be maintained in the vicinity of the large plain. Maintaining a high level of connectivity contributes to conservation strategies. The management of these areas aimed at connecting urban and rural areas could enhance landscape diversity (Velázqueza et al., 2019).

In order to minimize habitat loss, prevent fragmentation, and enhance ecological connectivity, spatial planners must implement alternative planning tools that are both effective and easy to utilize (Almenar et al., 2019). In order to ensure that ecological values are protected and used in a balanced manner, conservation methods must be investigated, analyzed, and planned; long-term processes must be examined and interventions must be made if necessary. During these processes, reference maps must be produced to guide planning decisions. The ecologicalconnectivity model suggested by Marulli and Mallarach (2005) is an effective method that can be applied to assess connectivity on a regional scale.

There is a clear association between the results that were obtained in this study and the problems stemming from a growing population and unplanned urbanization. One study currently being conducted is the Gediz Basin Action Plan, through which action-progression and evaluation meetings were organized in Manisa. The study discusses ecological aims in terms of water quality but there is still no sign of ecological-plan preparation in the basin. It is clear that mapping critical habitats in terms of ecological-connectivity restoration will significantly contribute to landscape planning and management. Authors recommend that a detailed habitat map of Manisa needs to be produced as a base for the holistic planning and management for the detailed ecological connectivity assessment. This map can be produced in a similar vein with the habitat map that was produced by Ersoy et al. (2019) for Dilek Peninsula-Büyük Menderes Delta National Park, Bafa Lake Natural Park, and the nearby wetland system.

As emphasized by Pino and Marull (2012) and Dupras et al. (2016), defining habitat corridors in planning areas helps to determine of a conservation strategy that can prevent the adverse effects of urban activities on natural connections. Consequently, the area with Yamanlar Volcano in the west and Spil Mountain in the east must be handled as a single conservation-area network. In a large landscape matrix, this mountainside serves as a west-to-east chain with Yamanlar Mountain National Park, Izmir Karagöl Natural Park, Süreyya Natural Park, Spil Mountain National Park, and Mesir Natural Park. Since these areas are in two separate cities located in neighboring provinces, Manisa and Izmir, they need to be considered at a regional scale for implementing conservation-based management. Therefore, authors strongly 
recommend that further studies should focus on ecological functional areas of Izmir. This will add value to enhance landscape management of both Izmir and Manisa.

The Law on Spatial Planning and Construction (CSB, 2014) anticipates high-level plans that enable the establishment of conservation areas while considering basin integrity. Considering this legislation and the results of this study, authors suggest that landscape analysis and assessment management which entails both ecological connectivity and landscape metrics be integrated into the spatial planning process.

There is an urgent need for policies in order to protect and restore particularly no-connectivity and low-connectivity areas in Manisa. Authors believe that, ecological connectivity loss that found in this study makes a contribution to the future strategic plan. For this reason, policy makers and land managers are expected to use the findings of this study to engage with new sets of conservation actions and to make sounder decisions.

\section{ACKNOWLEDGEMENTS}

This research did not receive any specific grant from funding agencies in the public, commercial, or not-for-profit sectors.

\section{References}

Almenar, J. B., Bolowich, A., Elliot, T., Geneletti, D., Sonnemann, G. \& Rugani, B. (2019). Assessing habitat loss, fragmentation and ecological connectivity in Luxembourg to support spatial planning. Landscape and Urban Planning, 189, 335-351.

Altan, Y., Aktaş, K. \& Suveren, Y. M. (2017). Flora of Beydere village (Manisa). Bilge International Journal of Science and Technology Research, 1(2), 143-154.

Arı, Y. \& Derinöz, B. (2011). How Not to Manage a Wetland? the Case of Lake Marmara (Manisa) with a cultural ecological perspective). Turkish Journal of Geographical Sciences, 9(1), 41-60.

Beier, P. \& Noss, R. F. (1998). Do habitat corridors provide connectivity? Conservation biology, 12(6), 1241-1252.

Carlier, J. \& Moran, J. (2019). Landscape typology and ecological connectivity assessment to inform Greenway design. Science of the Total Environment, 651, 3241-3252.

Chang, Q., Li, X., Huang, X. \& Wu, J. (2012). A GIS-based green infrastructure planning for sustainable urban land use and spatial development. Procedia Environmental Sciences, 12, 491-498.

Christensen, A. A., Brandt, J., \& Svenningsen, S. R. (2017). Landscape ecology. In D. Richardson, N. Castree, M. F. Goodchild, A. Kobayashi, W. Liu, \& R. A. Marston (Eds.), The international encyclopedia of geography: people, the earth, environment, and technology (pp. 1-10). New Jersey: Wiley.

Collinge, S. K. (1998). Spatial arrangement of habitat patches and corridors: clues from ecological field experiments. Landscape and Urban Planning, 42(2-4), 157-168.

Correa Ayram, C. A., Mendoza, M. E., Etter, A. \& Salicrup, D. R. P. (2016). Habitat connectivity in biodiversity conservation: A review of recent studies and applications. Progress in Physical Geography, 40(1), 7-37.

Crist, M. R., Wilmer, B. O. \& Aplet, G. H. (2005). Assessing the value of roadless areas in a conservation reserve strategy: biodiversity and landscape connectivity in the northern Rockies. Journal of Applied Ecology, 42(1), 181-191.

CSB, (2014). Çevre ve Şehircilik Bakanlığı mekânsal planlama genel müdürlüğü mekânsal planlar yapım yönetmeliği. 15 Mart 2020 tarihinde https://mpgm.csb.gov.tr/plan-gosterimleri-i-4926, adresinden edinilmiştir.

De Montis, A., Caschili, S., Mulas, M., Modica, G., Ganciu, A., Bardi, A., Ledda, A., Dessena, L., Laudari, L. \& Fichera, C. R. (2016). Urban-rural ecological networks for landscape planning. Land Use Policy, 50, 312-327.

DiLeo, M. F., Rico, Y., Boehmer, H. J. \& Wagner, H. H. (2017). An ecological connectivity network maintains genetic diversity of a flagship wildflower, Pulsatilla vulgaris. Biological conservation, 212, 12-21.

Dramstad, W., Olson, J. D. \& Forman, R. T. (1996). Landscape Ecology Principles in Landscape Architecture and Land-Use Planning. Washington: Island press.

Dupras, J., Marull, J., Parcerisas, L., Coll, F., Gonzalez, A., Girard, M. \& Tello, E. (2016). The impacts of urban sprawl on ecological connectivity in the Montreal Metropolitan Region. Environmental Science \& Policy, 58, 61-73.

EEA, (2019). European environment agency, copernicus land monitoring service. Retrieved from September 10, 2019, from https://land.copernicus.eu/pan-european/corine-land-cover.

Ersoy, E., Yılmaz, K. T., Atak, B. K. \& Gülçin, D. (2019). Sentinel-2A uydu görüntüsünde nesne tabanlı sınıflandırma yöntemi kullanılarak kıyı habitatlarının haritalanması. Afyon Kocatepe Üniversitesi Fen ve Mühendislik Bilimleri Dergisi, 19(1), $152-161$.

Fábos, J. G. \& Ryan, R. L. (2006). An introduction to greenway planning around the world. Landscape and Urban Planning, 76(1/4), 16.

Forman, R. T. (1995). Some general principles of landscape and regional ecology. Landscape Ecology, 10(3), $133-142$. 
García-Díaz, P., Anderson, D. P., \& Lurgi, M. (2019). Evaluating the effects of landscape structure on the recovery of an invasive vertebrate after population control. Landscape Ecology, 34(3), 615-626.

Goodwin, B. J. (2003). Is landscape connectivity a dependent or independent variable?. Landscape Ecology, 18(7), 687-699.

Gorguner, M., Kavvas, M. L. \& Ishida, K. (2019). Assessing the impacts of future climate change on the hydroclimatology of the Gediz Basin in Turkey by using dynamically downscaled CMIP5 projections. Science of the Total Environment, 648, 481-499.

Guan, B. C., Liu, X., Gong, X., Cai, Q. Y. \& Ge, G. (2019). Genetic landscape and landscape connectivity of Ceratopteris thalictroides, an endangered aquatic fern. Ecological Informatics, 53, 100973.

Gülersoy, A. E. (2013). Farkli uzaktan algilama teknikleri kullanilarak arazi örtüsü/kullaniminda meydana gelen değişimlerin incelenmesi: Manisa Merkez ilçesi örneği (1986-2010). Electronic Turkish Studies, 8(8), 1915-1934.

Hepcan, C. C. (2013). Quantifying landscape pattern and connectivity in a Mediterranean coastal settlement: the case of the Urla district, Turkey. Environmental Monitoring and Assessment, 185(1), 143-155.

Hesselbarth, M. H., Sciaini, M., With, K. A., Wiegand, K. \& Nowosad, J. (2019). landscapemetrics: an open-source R tool to calculate landscape metrics. Ecography, 42(10), 1648-1657.

Hodgson, J. A., Moilanen, A. \& Thomas, C. D. (2009). Metapopulation responses to patch connectivity and quality are masked by successional habitat dynamics. Ecology, 90(6), 1608-1619.

Indrayani, P., Mitani, Y., Djamaluddin, I. \& Ikemi, H. (2017). A GIS based evaluation of land use changes and ecological connectivity Index. Journal of Geomatics and Planning, 4(1), 9-18.

Işık-Gürsoy, D., Uğurlu, E. \& Oldeland, J. (2016). Plant communities, diversity and endemism of the Kula Volcano, Manisa, Turkey. Plant Biosystems, 150(5), 1046-1055.

Jongman, R. H. (2019). Connectivity and ecological networks. In Fath, B. (Ed.), Encyclopedia of ecology (pp. 366-376). Cambridge: Elsevier.

Jorgensen, S. E. \& Fath, B. D. (2014). Encyclopedia of ecology. Amsterdam: Newnes.

Kaplan, A. \& Hepcan, Ş. (2009). An examination of ecological risk assessment at landscape scale and the management plan. In T. S. Illangasekare, K. \& Mahutova, J. J. Barich (Eds.), Decision support for natural disasters and intentional threats to water security (pp. 237-251). Dordrecht: Springer.

Kocataş, A., Ergen, Z., Katağan, T., Koray, T., Büyükışık, B., Mater, D., Özel, I., Uçal, O. \& Önen, M. (1988). Effects of pollution on benthic and pelagic ecosystems of the Izmir Bay (Turkey). MAP Technical Reports Series, 2, 53-72.

LaPoint, S., Balkenhol, N., Hale, J., Sadler, J. \& van der Ree, R. (2015). Ecological connectivity research in urban areas. Functional Ecology, 29(7), 868-878.

Lavers, C. J. \& Haines-Young, R. (1993). Equilibrium landscapes and their aftermath: spatial heterogeneity and the role of new technology. Haines-Young, R., Green, DR, Cousins, S.,(Eds.), Landscape ecology and geographic information systems (pp 5975). New Jersey: Taylor and Francis.

Lindenmayer, D., Hobbs, R. J., Montague-Drake, R., Alexandra, J., Bennett, A., Burgman, M., Cale, P., Calhoun, A., Cramer, V., Cullen, P., Driscoll, D., Fahrig, L., Fischer, J., Franklin, J., Haila, Y., Hunter, M., Gibbons, P., Lake., S., Luck, G., MacGregor, C., Mclntyre, S., Nally, R. M., Manning, A., Miller, J., Mooney, H., Noss, R., Possingham, H., Saunders, D., Schmiegelow, F., Scott, M., Simberloff, D., Sisk, T., Tabor, G., Walker, B., Wiens, J., Woinarski, J. \& Zavaleta. E. (2008). A checklist for ecological management of landscapes for conservation. Ecology Letters, 11(1), 78-91.

Linehan, J., Gross, M. \& Finn, J. (1995). Greenway planning: developing a landscape ecological network approach. Landscape and Urban Planning, 33(1-3), 179-193.

Luque, S., Saura, S. \& Fortin, M. J. (2012). Landscape connectivity analysis for conservation: insights from combining new methods with ecological and genetic data. Landscape Ecology, 27(2), 153-157.

Mallarach, J. M. \& Marull, J. (2006). Impact assessment of ecological connectivity at the regional level: recent developments in the Barcelona Metropolitan Area. Impact Assessment and Project Appraisal, 24(2), 127-137.

Marulli, J. \& Mallarach, J. M. (2005). A GIS methodology for assessing ecological connectivity: application to the Barcelona Metropolitan Area. Landscape and Urban Planning, 71(2-4), 243-262.

McGarigal, K. (2002). Landscape pattern metrics. In: A. H. El-Shaarawi, \& W. W. Piegorsch, (Eds.), Encyclopedia of environmetrics (pp 1135-1142), Chichester: Wiley.

McGarigal, K., Cushman, S. A. \& Ene, E. (2012). FRAGSTATS v4: spatial pattern analysis program for categorical and continuous maps. Computer software program produced by the authors at the University of Massachusetts, Amherst.

McRae, B. H., Hall, S. A., Beier, P. \& Theobald, D. M. (2012). Where to restore ecological connectivity? Detecting barriers and quantifying restoration benefits. PloS one, 7(12), 1-12.

MV, (2020). Manisa Valiliği Çevre ve Şehircilik il Müdürlüğü Manisa II Çevre Durum Raporu. 13 Ocak 2020 tarihinde https://webdosya.csb.gov.tr/db/ced/icerikler/man-sa_2018_cdr_son-20191015130608.pdf, adresinden edinilmiştir.

Nor, A. N. M., Corstanje, R., Harris, J. A., Grafius, D. R. \& Siriwardena, G. M. (2017). Ecological connectivity networks in rapidly expanding cities. Heliyon, 3(6), 1-29. 
Nowosad, J. \& Stepinski, T. F. (2019). Information theory as a consistent framework for quantification and classification of landscape patterns. Landscape Ecology, 34(9), 2091-2101.

Olds, A. D., Pitt, K. A., Maxwell, P. S. \& Connolly, R. M. (2012). Synergistic effects of reserves and connectivity on ecological resilience. Journal of Applied Ecology, 49(6), 1195-1203.

Pino, J. \& Marull, J. (2012). Ecological networks: are they enough for connectivity conservation? A case study in the Barcelona Metropolitan Region (NE Spain). Land Use Policy, 29(3), 684-690.

Qian, J., Xiang, W. N., Liu, Y., \& Meng, X. (2018). Incorporating landscape diversity into greenway alignment planning. Urban Forestry \& Urban Greening, 35, 45-56.

Raison, R. J., Brown, A. G. \& Flinn, D. W. (2001). Criteria and Indicators for Sustainable Forest Management. New York: CABI.

Saura, S., Estreguil, C., Mouton, C. \& Rodríguez-Freire, M. (2011). Network analysis to assess landscape connectivity trends: application to European forests (1990-2000). Ecological Indicators, 11(2), 407-416.

Taylor, J., Paine, C. \& FitzGibbon, J. (1995). From greenbelt to greenways: four Canadian case studies. Landscape and Urban Planning, 33(1-3), 47-64.

Taylor, P. D., Fahrig, L., Henein, K. \& Merriam, G. (1993). Connectivity is a vital element of landscape structure. Oikos, 68(3), $571-573$.

Tischendorf, L. \& Fahrig, L. (2000). On the usage and measurement of landscape connectivity. Oikos, 90(1), 7-19.

Tscharntke, T., Clough, Y., Wanger, T. C., Jackson, L., Motzke, I., Perfecto, Vandermeer, J. \& Whitbread, A. (2012). Global food security, biodiversity conservation and the future of agricultural intensification. Biological Conservation, 151(1), 53-59.

TUIK, (2019). Turkish Statistical Institute. Retrieved November 15, 2019 from http://www.tuik.gov.tr/PreTablo.do?alt_id=1047.

Turner, M. G. (1989). Landscape ecology: the effect of pattern on process. Annual Review of Ecology and Systematics, 20(1), 171-197.

Uuemaa, E., Antrop, M., Roosaare, J., Marja, R. \& Mander, Ü. (2009). Landscape metrics and indices: an overview of their use in landscape research. Living Reviews in Landscape Research, 3(1), 1-28.

Velázquez, J., Gutiérrez, J., García-Abril, A., Hernando, A., Aparicio, M. \& Sánchez, B. (2019). Structural connectivity as an indicator of species richness and landscape diversity in Castilla y León (Spain). Forest Ecology and Management, 432, 286-297.

Vizzari, M., Hilal, M., Sigura, M., Antognelli, S. \& Joly, D. (2018). Urban-rural-natural gradient analysis with CORINE data: An application to the metropolitan France. Landscape and Urban Planning, 171, 18-29.

Vogiatzakis, I. N., Mannion, A. M. \& Griffiths, G. H. (2006). Mediterranean ecosystems: problems and tools for conservation. Progress in Physical Geography, 30(2), 175-200.

Watson, D. M., Doerr, V. A., Banks, S. C., Driscoll, D. A., van der Ree, R., Doerr, E. D. \& Sunnucks, P. (2017). Monitoring ecological consequences of efforts to restore landscape-scale connectivity. Biological Conservation, 206, 201-209.

Wu, L. Y., He, D. J., You, W. B., Ji, Z. R., Tan, Y. \& Zhao, L. L. (2017). The dynamics of landscape-scale ecological connectivity based on least-cost model in Dongshan Island, China. Journal of Mountain Science, 14(2), 336-345.

Yazgi, D., Yilmaz, K. T. (2017). The evaluation of landscape typology and richness for achieving conservation priorities of habitats. Ekoloji 2017 Uluslararası Sempozyumu'nda sunulmuştur. Kayseri, Türkiye.

Zhang, Z., Meerow, S., Newell, J. P. \& Lindquist, M. (2019). Enhancing landscape connectivity through multifunctional green infrastructure corridor modeling and design. Urban Forestry \& Urban Greening, 38, 305-317.

Zwoliński, Z., Najwer, A. \& Giardino, M. (2018). Methods for assessing geodiversity. In E. Reynard \& J. Brilha (Eds.), Geoheritage (pp. 27-52). Amsterdam: Elsevier. 